\title{
Role of Investment, Inflation and Unemployment on Tax Collection of Pakistan
}

\author{
Mohammad Salih Memon \\ Assistant Professor, Department of Business Administration* \\ saleh.memon@salu.edu.pk \\ Dr. Asad RazaAbdi \\ Assistant Professor, Department of Economics* \\ Mr. Sarmad Rahat \\ Lecturer, Department of Economics* \\ *Shah Abdul Latif University Khairpur, Sindh, Pakistan
}

\section{Abstract}

\begin{abstract}
The major development variables was checked by the effects of taxation by using linear regression, and looking at the results and their discussions it is very clearly observed by the researchers that increased tax collection will boost the inflation, means producers are shifting the burden of taxes on the consumers which is not a good sign for the smooth economic system, and tax collections are not purely concerned with the investment means investors are not looking for the tax shelter or rebate but only they are looking to the opportunities, and finally tax collection have negative impact on Un-employment rate, which states that improved tax collections are properly utilized in productive opportunities in the result un-employment rate is decreasing.
\end{abstract}

\section{Council for Innovative Research}

Peer Review Research Publishing System

Journal: International Journal of Management \& Information Technology

Vol. 10 No. 2

editorsijmit@gmail.com

www.ijmit.com/ois 


\section{Introduction}

This type of research is keen requirement of the economy of Pakistan especially for financial, public sectors; this research will help to policy makers in identifying the role of taxation in formulation of economic policies for Pakistan that will ultimately lead towards the economic growth which still policy makers are planning but difficult to achieve.

Tax revenue is the income of governments that generated from side to side the levy of the inhabitants. It includes levy on manufacturing and imports, present duty on earnings and capital, money gains duty and social assistance. And a welldesigned structure of tax within the country is not only improving the competitiveness economic and industrial sector but also contributing for motivating economic activities so for the growth in the economy. Pakistan's tax system is not functioning accordingly because of structural weaknesses for example:

1. Narrow tax base,

2. Massive tax evasions

3. Administrative weaknesses

Despite the enhancement in tax collection/revenue, tax to GDP ratio of FBR is varying only between 8.5-9.6\% during the last twelve years. Now a days Pakistan's tax structure is distortionary and incentivizing massive tax evasion (E-Survey, 2012-2013).

There is a general view about the GDP ratio, that it can be increased only when all the sectors of economy contribute properly to the tax revenue

Figure:1 FBR Tax Revenue as Percentage of

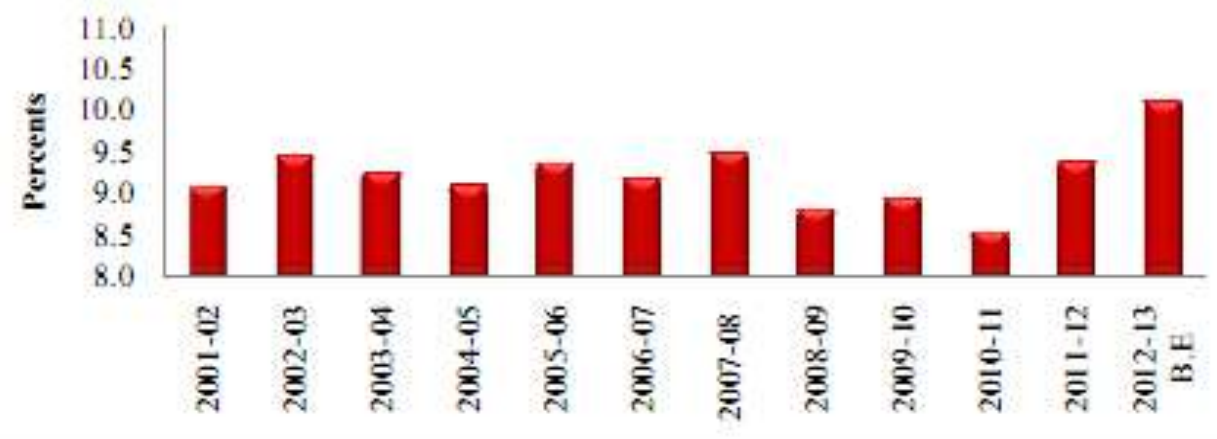

Source: Economic Survey of Pakistan 2012-13.

In order to raise the tax income like a percentage of Gross Domestic Production, levy policy of Pakistan is primly focusing on buoyancy of tax system, in broadening the tax base, and distortions are trying to be reduced, and exemptions are phased out. 
Table: 1 Structure of Federal Tax Revenue (in millions)

\begin{tabular}{|c|c|c|c|c|c|c|c|}
\hline \multirow[t]{2}{*}{ Year } & \multirow[t]{2}{*}{ Total (FBR) } & \multirow{2}{*}{$\begin{array}{c}\text { Tax Rev as } \% \\
\text { of GDP }\end{array}$} & \multirow[t]{2}{*}{ Direct Taxes } & \multicolumn{4}{|c|}{ Indirect Taxes } \\
\hline & & & & Customs & Sales & Excise & Total \\
\hline \multirow[t]{2}{*}{$2001-02$} & \multirow[t]{2}{*}{404.1} & \multirow[t]{2}{*}{9.2} & 142.5 & 47.8 & 166.6 & 47.2 & 261.6 \\
\hline & & & {$[35.3]$} & $\{18.3\}$ & $\{63.7\}$ & $\{18\}$ & $\overline{[64.7]}$ \\
\hline \multirow[t]{2}{*}{$2002-03$} & \multirow[t]{2}{*}{460.6} & \multirow[t]{2}{*}{9.6} & 151.9 & 68.8 & 195.1 & 44.8 & 308.7 \\
\hline & & & {$[33.0]$} & $\{22.3\}$ & $\{63.2\}$ & $\{14.5\}$ & {$[67.0]$} \\
\hline \multirow[t]{2}{*}{$2003-04$} & \multirow[t]{2}{*}{520.9} & \multirow[t]{2}{*}{9.2} & 165.1 & 91.0 & 219.2 & 45.6 & 355.8 \\
\hline & & & {$[31.7]$} & $\{25.6\}$ & $\{61.6\}$ & $\{12.8\}$ & {$[68.3]$} \\
\hline \multirow[t]{2}{*}{ 2004-05 } & \multirow[t]{2}{*}{590.4} & \multirow[t]{2}{*}{8.9} & 183.4 & 115.4 & 238.5 & 53.1 & 407.0 \\
\hline & & & {$[30.1]$} & $\{28.4\}$ & $\{58.6\}$ & $\{13.0\}$ & {$[68.9]$} \\
\hline \multirow[t]{2}{*}{$2005-06$} & \multirow[t]{2}{*}{713.5} & \multirow[t]{2}{*}{9.4} & 225.0 & 138.4 & 294.8 & 55.3 & 488.5 \\
\hline & & & {$[31.5]$} & $\{28.3\}$ & $\{60.3\}$ & $\{11.3\}$ & [68.5] \\
\hline \multirow[t]{2}{*}{$2006-07$} & \multirow[t]{2}{*}{847.2} & \multirow[t]{2}{*}{9.2} & 333.7 & 132.3 & 309.4 & 71.8 & 513.5 \\
\hline & & & {$[39.4]$} & $\{25.8\}$ & $\{60.3\}$ & $\{14.0\}$ & {$[60.6]$} \\
\hline \multirow[t]{2}{*}{$2007-08$} & \multirow[t]{2}{*}{$1,008.1$} & \multirow[t]{2}{*}{9.5} & 387.9 & 150.7 & 377.4 & 92.1 & 620.2 \\
\hline & & & {$[38.5$} & $\{24.3\}$ & $\{60.9\}$ & $\{14.9\}$ & [61.5] \\
\hline \multirow[t]{2}{*}{$2008-09$} & \multirow[t]{2}{*}{$1,161.1$} & \multirow[t]{2}{*}{8.8} & 443.5 & 148.4 & 451.7 & 117.5 & 717.6 \\
\hline & & & {$[38.2]$} & $\{20.7\}$ & $\{62.9\}$ & $\{16.4\}$ & {$[61.8]$} \\
\hline \multirow[t]{2}{*}{$2009-10$} & \multirow[t]{2}{*}{$1,327.4$} & \multirow[t]{2}{*}{8.9} & 526.0 & 160.3 & 516.3 & 124.8 & 801.4 \\
\hline & & & {$[39.6]$} & $\{20.0\}$ & $\{64.4\}$ & $\{15.6\}$ & {$[60.4]$} \\
\hline $2010-11$ & $1,558.2$ & 8.5 & 602.5 & 184.9 & 633.4 & 137.4 & 955.7 \\
\hline & & & {$[38.7]$} & $\{19.3\}$ & $\{66.3\}$ & $\{14.4\}$ & {$[61.3]$} \\
\hline $2011-12$ & $1,882.7$ & 9.4 & 738.4 & 216.9 & 804.9 & 122.5 & $1,144.3$ \\
\hline & & & {$[39.2]$} & $\{19.0\}$ & $\{70.3\}$ & $\{10.7\}$ & {$[60.8]$} \\
\hline 2012-13 B.E & $2,381.0$ & 10.1 & 932.0 & 247.5 & 1076.5 & 125.0 & $1,449.0$ \\
\hline & & & {$[39.1]$} & $\{17.1\}$ & $\{74.3\}$ & $\{8.0\}$ & {$[60.9]$} \\
\hline
\end{tabular}

Source: Federal Board of Revenue

$\{$ as $\%$ of indirect taxes

Table: 2 Summaries of Open Market Operations

\begin{tabular}{|c|c|c|c|c|}
\hline \multicolumn{3}{|c|}{ Summary of OMO's } & \multicolumn{2}{|r|}{ (Rs. billion) } \\
\hline & \multicolumn{2}{|c|}{ Injections } & \multicolumn{2}{|c|}{ Absorptions } \\
\hline & 2011-12 & $2012-13$ & 2011-12 & $2012-13$ \\
\hline July & 408.5 & $1,058.6$ & - & 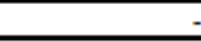 \\
\hline August & 640.4 & $2,090.1$ & - & $=$ \\
\hline September & $1,025.1$ & $2,095.6$ & - & 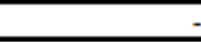 \\
\hline October & $1,058.7$ & $2,505.1$ & - & 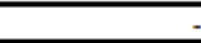 \\
\hline November & $1,381.5$ & $2,633.2$ & - & 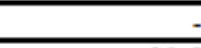 \\
\hline December & $1,418.9$ & $2,404.4$ & 24.0 & 39.5 \\
\hline January & 969.2 & $2,480.2$ & - & 107.0 \\
\hline February & $1,244.4$ & $2,231.6$ & - & $=$ \\
\hline March & $1,210.9$ & $2,322.5$ & 3.0 & 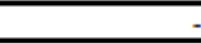 \\
\hline Total & 9.357 .4 & $19,821.1$ & 27.0 & 146.5 \\
\hline
\end{tabular}


Table: 3 Unemployed Pakistan and Provinces (in millions)

\begin{tabular}{|c|c|c|c|c|c|c|c|c|c|}
\hline \multirow[t]{3}{*}{ Province /Area } & \multicolumn{9}{|c|}{ Unemployment } \\
\hline & \multicolumn{3}{|c|}{$2008-09$} & \multicolumn{3}{|c|}{$2009-10$} & \multicolumn{3}{|c|}{$2010-11$} \\
\hline & Total & Male & Female & Total & Male & Female & Total & Male & Female \\
\hline Pakistan & 2.93 & 1.87 & 1.06 & 3.12 & 1.91 & 1.21 & 3.40 & 2.22 & 1.18 \\
\hline Rural & 1.76 & 1.06 & 0.70 & 1.89 & 1.12 & 0.77 & 1.85 & 1.14 & 0.71 \\
\hline Urban & 1.17 & 0.81 & 0.36 & 1.23 & 0.79 & 0.44 & 1.55 & 1.08 & 0.47 \\
\hline Punjab & 1.87 & 1.21 & 0.66 & 1.94 & 1.18 & 0.76 & 2.10 & 1.31 & 0.79 \\
\hline Rural & 1.14 & 0.70 & 0.44 & 1.16 & 0.68 & 0.48 & 1.25 & 0.76 & 0.49 \\
\hline Urban & 0.73 & 0.51 & 0.22 & 0.78 & 0.50 & 0.28 & 0.85 & 0.55 & 0.30 \\
\hline Sindh & 0.44 & 0.28 & 0.16 & 0.57 & 0.35 & 0.22 & 0.70 & 0.54 & 0.16 \\
\hline Rural & 0.14 & 0.06 & 0.08 & 0.24 & 0.12 & 0.12 & 0.15 & 0.10 & 0.05 \\
\hline Urban & 0.30 & 0.22 & 0.08 & 0.33 & 0.23 & 0.10 & 0.55 & 0.44 & 0.11 \\
\hline KPK & 0.56 & 0.36 & 0.20 & 0.55 & 0.35 & 0.20 & 0.53 & 0.32 & 0.21 \\
\hline Rural & 0.44 & 0.29 & 0.15 & 0.45 & 0.29 & 0.16 & 0.41 & 0.25 & 0.16 \\
\hline Urban & 0.12 & 0.07 & 0.05 & 0.10 & 0.06 & 0.04 & 0.12 & 0.07 & 0.05 \\
\hline Balochistan & 0.06 & 0.02 & 0.04 & 0.06 & 0.03 & 0.03 & 0.07 & 0.05 & 0.02 \\
\hline Rural & 0.04 & 0.01 & 0.03 & 0.04 & 0.02 & 0.02 & 0.04 & 0.03 & 0.01 \\
\hline Urban & 0.02 & 0.01 & 0.01 & 0.02 & 0.01 & 0.01 & 0.03 & 0.002 & 0.01 \\
\hline
\end{tabular}

Source: Labour Force Survev 2010-11

\section{Employment Promotion Policies by the Government of Pakistan}

These policies of government are purely in creation of job market, and human resource development in addressing the following areas:

1. Sectorial Development,

2. Micro Credit Facilities Through SME Bank,

3. Micro Credit Facilities Through Khushali Bank,

4. President Rozgar Scheme by National Bank of Pakistan,

5. Information Technology,

6. Overseas Employment,

7. National Internship Program,

8. Pakistan Skilling Program, and

9. Employment by Sectors

Table: 4 Regional Countries Human Development Indicator

\begin{tabular}{|c|c|c|c|c|c|}
\hline Country & $\begin{array}{c}\text { Life } \\
\text { Expectancy } \\
2012\end{array}$ & $\begin{array}{c}\text { Infant Mortality } \\
\text { Rate } \\
\text { Per } 1000 \\
2011\end{array}$ & $\begin{array}{c}\text { Under } 5 \text { Mortality } \\
\text { Rate } \\
\text { Per } 1000 \\
2011\end{array}$ & $\begin{array}{c}\text { Maternal Mortality } \\
\text { Rate } \\
\text { Per } 100000 \\
2010\end{array}$ & $\begin{array}{l}\text { Population } \\
\text { Growth } \\
\text { Rate(\%) } \\
2012\end{array}$ \\
\hline Pukistan & 65.7 & 59 & 72 & 260 & $2.03^{*}$ \\
\hline India & 65.8 & 47 & 61 & 200 & 1.31 \\
\hline Bangladesh & 69.2 & 37 & 46 & 240 & 1.58 \\
\hline Sri Lanka & 75.1 & 11 & 12 & 35 & 0.91 \\
\hline Nepal & 69.1 & 39 & 48 & 170 & 1.77 \\
\hline Bhutan & 68.0 & 42 & 54 & 180 & 1.18 \\
\hline China & 73.7 & 13 & 15 & 37 & 0.48 \\
\hline Malaysia & 74.5 & 06 & 07 & 29 & 1.57 \\
\hline Indonesia & 69.8 & 25 & 32 & 220 & 1.03 \\
\hline Philippines & 69.0 & 20 & 25 & 99 & 1.87 \\
\hline Thailand & 74.3 & 11 & 12 & 48 & 0.54 \\
\hline
\end{tabular}


Table 5 Composition of CPI Inflation

\begin{tabular}{|c|c|c|c|c|c|c|}
\hline \multirow[t]{2}{*}{ Commodity } & \multirow[t]{2}{*}{ Weights } & \multicolumn{2}{|c|}{$\%$ Change Inflation } & \multicolumn{2}{|c|}{ Point Contribution } & \multirow{2}{*}{$\begin{array}{c}\% \% \\
\text { Contribution }\end{array}$} \\
\hline & & $2011-12$ & $2012-13$ & $2011-12$ & $2012-13$ & \\
\hline General (CPI) & 100.0 & 10.8 & 7.8 & 10.8 & 7.8 & 100.0 \\
\hline Food, \& Non Alcoholic Beverages & 34.83 & 11.1 & 6.6 & 3.9 & 2.3 & 29.8 \\
\hline Non-Food & 65.17 & 10.7 & 8.5 & 6.9 & 5.5 & 71.3 \\
\hline Alcoholic Beverages \& Tobacoo & 1.41 & 7.5 & 17.5 & 0.1 & 0.2 & 3.2 \\
\hline Clothing \& Foot wear & 7.57 & 14.9 & 14.7 & 1.1 & 1.1 & 14.4 \\
\hline Housing, Water, Elec. Gas \& other Fuel & 29.41 & 7.5 & 4.1 & 2.2 & 1.2 & 15.6 \\
\hline Furnishing \& Household Equipments & 4.21 & 17.4 & 13.3 & 0.7 & 0.6 & 7.2 \\
\hline Health & 2.19 & 11.1 & 14.2 & 0.2 & 0.3 & 4.0 \\
\hline Transport & 7.20 & 15.5 & 10.5 & 1.1 & 0.8 & 9.7 \\
\hline Communications & 3.22 & 0,6 & 2.2 & 0.0 & 0.1 & 0.9 \\
\hline Recreation \& Culture & 2.03 & 5.7 & 18.3 & 0.1 & 0.4 & 4.8 \\
\hline Education & 3.94 & 12.3 & 9.3 & 0.5 & 0.4 & 4.7 \\
\hline Restaurant \& Hotels & 1.23 & 12.8 & 9.9 & 0.2 & 0.1 & 1.6 \\
\hline Miscellaneous & 2.07 & 19.9 & 10.6 & 0.4 & 0.2 & 2.8 \\
\hline
\end{tabular}

Figure: 2 Historical Trends in CPI

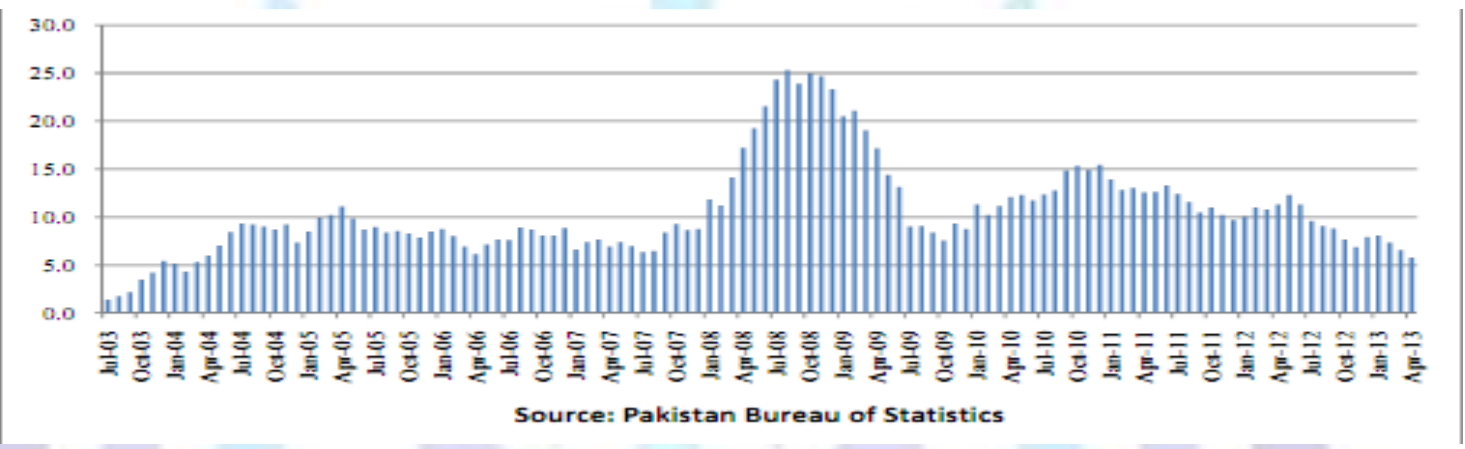
Source: Pakistan Bureau of Statistics

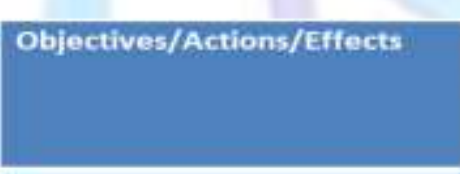

National un-employment rate rises

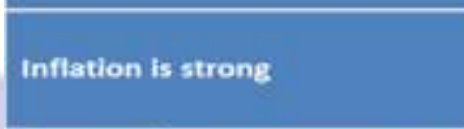

Surveys show consumers are loosing confidence in the economy, retail sales are weak and business

Inventories are increasing rapidly

Business sales and

investment are expanding rapidly, and economists think strong inflation lles ahead

Inflation persists while unemployment stays high

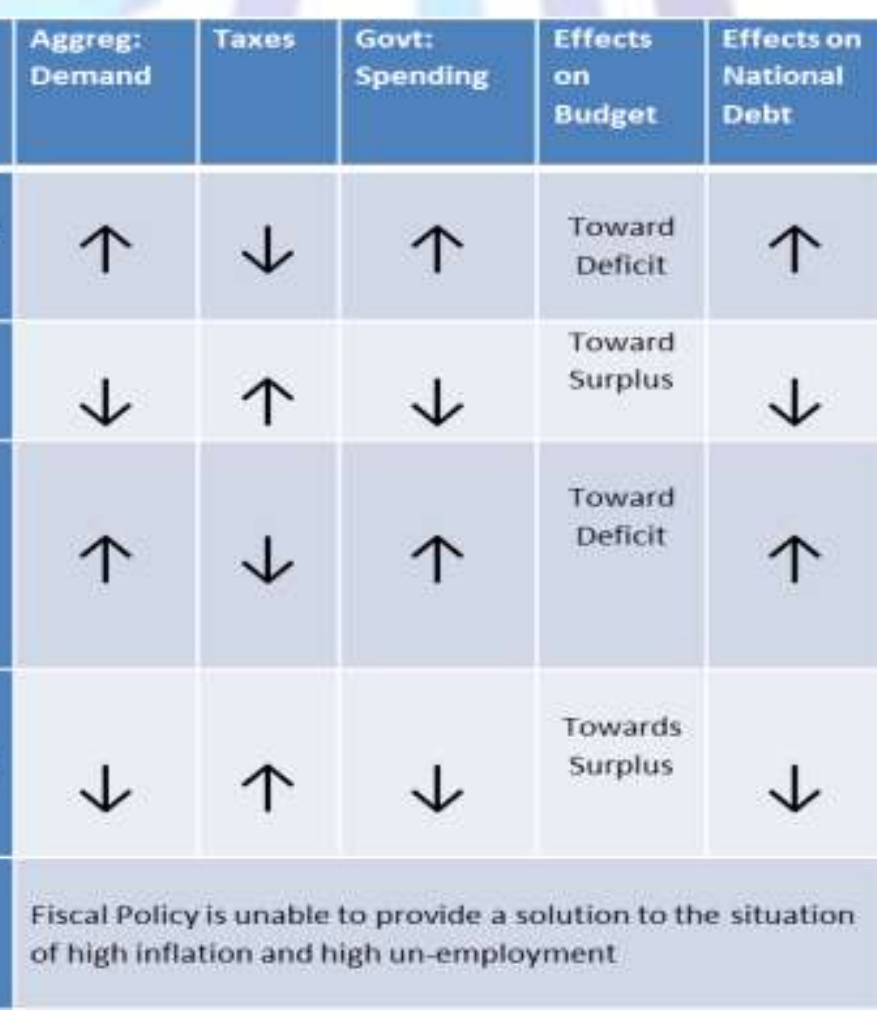




\section{Literature Review}

(Lewis, 1982) Suggested with the intention of behavior must be scrutinize for the level in the direction of which they are the output of fable as well as misperception. He quarrel that whenever mythology and misperceptions are put back with the acquaintance a revolutionize in behavior for tax will take place yet if essential thought and core values of tax payers stay unchanged along with the law regarding the tax unbothered.In the conclusion the governments should prudently spending money in different ways at the level of compliance.

A modern research accomplished by (Richardson, 2008) recommended with the aim of position of government got considerable and optimistic impact on identifying the mind-set towards tax collection. There is broad range of affordable mechanism for giving a shelter to poor from taxes on their income. As the governor of Hawaii, Linda Ingle said in her state address in 2006, "the bottom line is that we are collecting income taxes from people who simply cannot afford to pay them". Many states would do fit to pay attention to her vocabulary.

(Daveri \& Tabellini, 2000) Passed the argument that reasons for sluggish of economic growth inside Europe after war episode is the rapid growth in labor cost, and the labor cost increased only for the reason that high levy on labor earnings, amongst extra reasons.

(Clark, 1993) explored the conduct of trade with regard to utensils investment especially within United States of America from 1953-1992, he anticipated that enhance in taxes by $1 \%$ will reduce apparatus investment with $0.40 \%$.

Research of (Cummins, Jason, Kevin, \& Glen, 1996) used the data across the country comparison, they inspect the impact of levy restructuring on investment decision of over 3000 companies from 1981-1992 within 14 countries. The authors calculated that alteration within tax plan did really concern investment intensity in 12 among 14 countries, along with Canada.

A associated issue of impact of levy on investment revenue by (Chetty \& Emmanuel, 2004) analyzed the effects of 2003 dividend levy cut inside United States of America, which decreased the personage income tax load on the dividend from utmost rate of $35-15 \%$, they used the data from 1980-2004 and found wide and sharp surge in the payment of dividends by companies following the tax cut.

(Bruce \& Mohsin, 2006) offered a pragmatic analysis of tax plan as well as private enterprise within United States of America, they analyzed the individual income tax tariff, assets gain taxes, plus company income tax tariff on the rates of self-employment, and they found that $1 \%$ decrease in capital gain tax rate is negatively associated with self-employment rate about 0.11 to $0.15 \%$.

As noted by Keynesian the main idea of fiscal plan is to protected full employment plus the core gauge for referee between various responses of the policy was there employment conception effects (Kregel, 2008).

Considerable advantage for general public in china has been raising economic autonomy; the scope of private investment has been increasing, type of freedom in the sense that number of consumer goods and services are available and too much ability is there for moving in china and abroad as well. There is progress in rules of law improvement in China but liberties and politicians are restricted (Qain \& Wu, 2008)

\section{Methodology}

Data was collected through secondary source of information from ministry of finance government of Pakistan and the economic development variables used as dependent variables for analysis are: (Investment, Inflation and Un-employment Rate) from 2000-01 to 2009-10 linear regression was applied to check the degree of association of variables by applying the diagnostic tests:

\section{Results and Discussions}

$\mathrm{CPI}=\alpha+\mathrm{TC} \beta+\mu$

\section{Model Summary}

\begin{tabular}{|l|l|l|l|l|}
\hline Model & $R$ & R Square & $\begin{array}{l}\text { Adjusted } \\
\text { Square }\end{array}$ & $\begin{array}{l}\text { Rtd. Error of the } \\
\text { Estimate }\end{array}$ \\
\hline 1 & $.990^{\mathrm{a}}$ & .980 & .977 & 5.94007 \\
\hline
\end{tabular}

a. Predictors: (Constant), Tax Collection

Results of model summary (R-Square) states that variable entered as independent is rightly predicting the dependent variable because of error term is only $2 \%$ 


\section{Coefficients $^{\mathrm{a}}$}

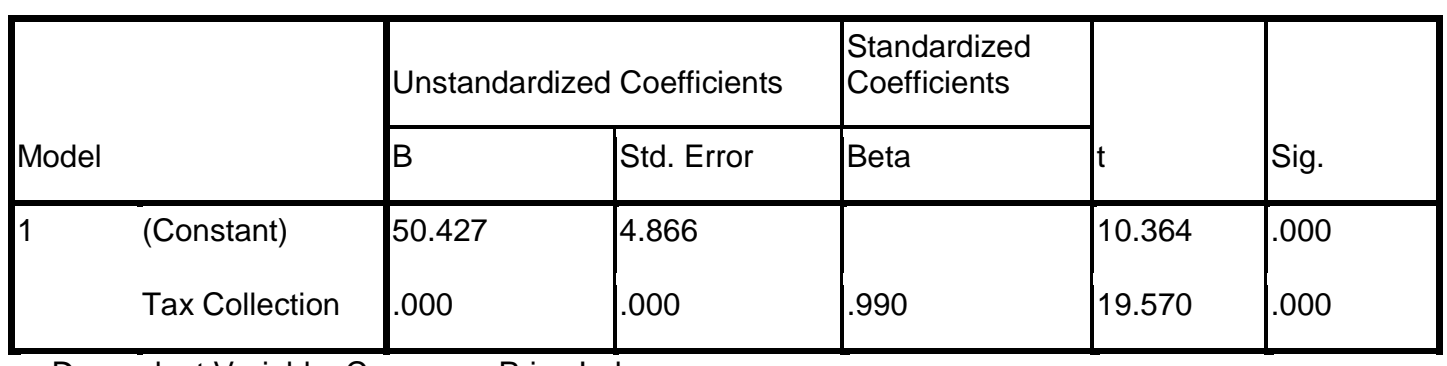

a. Dependent Variable: Consumer Price Index

And the Tax Collection is highly and positively correlated with the CPI

$$
\ln =\alpha+\operatorname{TC} \beta+\mu
$$

\section{Model Summary}

\begin{tabular}{|l|l|l|l|l|}
\hline Model & $R$ & $R$ Square & $\begin{array}{l}\text { Adjusted } \\
\text { Square }\end{array}$ & $\begin{array}{l}\text { Std. Error of the } \\
\text { Estimate }\end{array}$ \\
\hline 1 & $.661^{\mathrm{a}}$ & .438 & .367 & 76893.26299 \\
\hline
\end{tabular}

a. Predictors: (Constant), Tax Collection

As the value of coefficient of determination is not too much higher, this states that explanatory power of the regression equation is not as good as to be.

\section{Coefficients $^{\mathrm{a}}$}

\begin{tabular}{|ll|l|l|l|l|l|l|}
\hline \multicolumn{2}{|l|}{} & \multicolumn{2}{|l|}{ Unstandardized Coefficients } & \multicolumn{2}{l|}{$\begin{array}{l}\text { Standardized } \\
\text { Coefficients }\end{array}$} & & \multirow{2}{*}{} \\
\cline { 3 - 6 } Model & & $\mathrm{B}$ & Std. Error & Beta & $\mathrm{t}$ & Sig. \\
\hline 1 & (Constant) & -52986.982 & 62983.502 & & -.841 & .425 \\
& Tax Collection & .175 & .070 & .661 & 2.495 & .037 \\
\hline
\end{tabular}

a. Dependent Variable: Net Investments

Tax collection is positively associated with the net investments

$$
\text { UER }=\alpha+\operatorname{TC} \beta+\mu
$$

\section{Model Summary}

\begin{tabular}{|l|l|l|lr|l|}
\hline Model & $R$ & $R$ Square & $\begin{array}{l}\text { Adjusted } \\
\text { Square }\end{array}$ & $\begin{array}{l}\text { Std. Error of the } \\
\text { Estimate }\end{array}$ \\
\hline 1 & $.696^{\mathrm{a}}$ & .484 & .420 & .93166 \\
\hline
\end{tabular}

a. Predictors: (Constant), Tax Collection

It is very much clear from the above table that regression model applied is exactly fit and significant which further states that explanatory power of the regression equation will not be the as good as to be, and can not better predict the dependent variable. 


\section{Coefficients $^{\mathrm{a}}$}

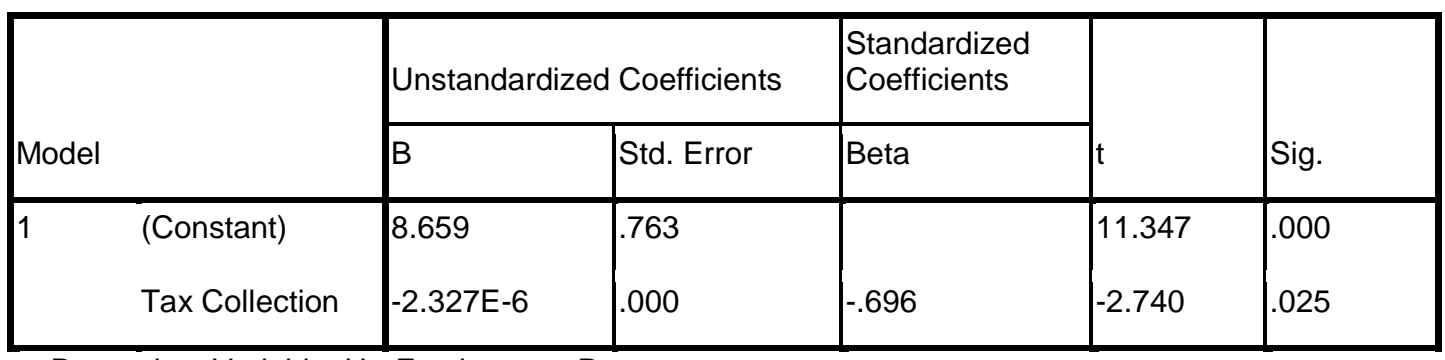

a. Dependent Variable: Un-Employment Rate

By looking at the results model is not fit according to the value of coefficient of determination and tax collection id negatively related to the un-employment rate.

\section{Conclusion}

While looking at the results and their discussions it is very clearly observed by the researchers that increased tax collection will boost the inflation, means producers are shifting the burden of taxes on the consumers which is not a good sign for the smooth economic system, and tax collections are not purely concerned with the investment means investors are not looking for the tax shelter or rebate but only they are looking to the opportunities, and finally tax collection have negative impact on Un-employment rate, which states that improved tax collections are properly utilized in productive opportunities in the result un-employment rate is decreasing.

\section{References}

1. Bruce, D., \& Mohsin, M. (2006). Tax Policy and Entrepreneurship: New Time Series Evidence. Small Business Economics 26(4), 09-25.

2. Chetty, R., \& Emmanuel, S. (2004). Do Dividend Payments Respond to Taxes? Preliminary Evidence from the 2003 Dividend Tax Cut. NBER Working Paper 10572 National Bureau of Economic Research.

3. Clark, P. (1993). Tax Incentives and Equipment Investment. Brookings Papers on Economic Activity , $317-339$.

4. Cummins, Jason, Kevin, H., \& Glen, H. (1996). Tax Reforms and Investments: A Cross-Country Comparison. Journal of Public Economics 62(1) , 237-273.

5. Daveri, F., \& Tabellini, G. (2000). Unemployment, Growth and Taxation in Industrial Countries. Economic Policy 15(30) , 47-104.

6. E-Survey. (2012-2013). Economic Survey of Pakistan. Ministry of Finance, Government of Pakistan .

7. Kregel, J. A. (2008). The Continuing Policy Relevance of Keynes's General Theory. In M. Foster and L.R. Wray (eds) Keynes for the 21st Century: The Continuing Relevance of the General Theory London .

8. Lewis. (1982). The Psychology of taxation. Oxford: Martin Robertson.

9. Qain, Y., \& Wu, J. (2008). Transformation in China. In J. Kornai, L. Mattyas, \& G. Roland, Institutional Change and Economic Behavior. UK, and New York.

10. Richardson, G. (2008). The relationship between culture and tax evasion across countries:Addational evidence and extensions. Journal of international accounting, auditing and taxation , 17(2), 67-78. 